History of Political Thought 
Also by John Morrow

T. H. Green: Lectures on the Principles of Political Obligation and Other Writings (with Paul Harris)

Coleridge's Political Thought

Coleridge's Writings: On Politics and Society

A History of English Political Thought in the Nineteenth Century

(with Mark Francis) 


\section{History of Political Thought}

A Thematic Introduction

John Morrow 


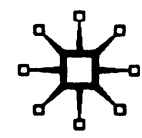

- John Morrow 1998

All rights reserved. No reproduction, copy or transmission of this publication may be made without written permission.

No paragraph of this publication may be reproduced, copied or transmitted save with written permission or in accordance with the provisions of the Copyright, Designs and Patents Act 1988, or under the terms of any licence permitting limited copying issued by the Copyright Licensing Agency, 90 Tottenham Court Road, London WIP OLP.

Any person who does any unauthorised act in relation to this publication may be liable to criminal prosecution and civil claims for damages.

The author has asserted his right to be identified as the author of this work in accordance with the Copyright, Designs and Patents Act 1988.

Published by

PALGRAVE

Houndmills, Basingstoke, Hampshire RC21 6XS and 175 Fifth Avenue, New York, N. Y. 10010

Companies and representatives throughout the world

PALGRAVE is the new global academic imprint of St. Martin's Press LLC Scholarly and Reference Division and Palgrave Publishers Ltd (formerly Macmillan Press Ltd).

ISBN 978-0-333-63221-5 ISBN 978-1-349-25939-7 (eBook) DOI 10.1007/978-1-349-25939-7

This book is printed on paper suitable for recycling and made from fully managed and sustained forest sources.

A catalogue record for this book is available from the British Library.

$\begin{array}{lllllllll}10 & 9 & 8 & 7 & 6 & 5 & 4 & 3 & 2\end{array}$

$\begin{array}{lllllllll}09 & 08 & 07 & 06 & 05 & 04 & 03 & 02 & 01\end{array}$ 
For Ruth Cook and in memory of Bill 


\section{Contents}

Preface

xiii

List of 'Thinker' Boxes $\quad$ XV

$\begin{array}{ll}\text { Introduction } & \mathbf{1}\end{array}$

Periodisation $\quad 2$

The focus of the Book 3

Western political thinking: a brief overview 5

$\begin{array}{ll}\text { Themes } & 13\end{array}$

$\begin{array}{lll}\text { PART I THE ENDS OF POLITICS } & 17\end{array}$

1 Politics and Order $\quad 19$

Cooperative order in ancient political theory: Protagoras,

Democritus, Plato and Aristotle 20

Negative and positive conceptions of order in medieval political theory: St Augustine and St Thomas Aquinas

Order and sovereignty in early modern political theory: Bodin, Grotius and Hobbes

Order, authoritarianism and totalitarianism in modern political theory: Carlyle, Maurras, Mussolini and Hitler

Cooperation and order in modern political theory:

Rousseau, Kant and Green

Order without politics: Anarchism and Marxism 46

$\begin{array}{ll}\text { Conclusion } & 48\end{array}$

2 Politics and Virtue $\quad \mathbf{5 0}$

Politics and virtue in ancient political theory: Plato and Aristotle 51

Virtue, politics and Christianity: Aquinas, Machiavelli, Luther, Calvin and radical protestantism 
Virtue, perfection and freedom: Kant and the British idealists 68

Conclusion $\quad 72$

3 Politics and Freedom $\quad 74$

Freedom and politics in the classical republican tradition:

Marsilius, Bartolus and Machiavelli $\quad 75$

Politics and 'natural' liberty:

Locke, Paine, J. S. Mill 77

Freedom, sociability and the state: Rousseau, Hegel and Green 84

Social freedom and the critique of state theory:

Marx

Freedom and anarchy: Godwin, Proudhon, Bakunin,

Kropotkin, Stirner, Warren and Tucker

Conclusion

4 Politics, Happiness and Welfare

Early utilitarianism: Paley, Saint-Pierre, Hume, Helvetius and Beccaria

Benthamite utilitarianism: Bentham, J. S. Mill, Sidgwick

The diffusion of utilitarianism: socialism and welfare

Conclusion

\section{PART II THE LOCATION OF POLITICAL AUTHORITY: WHO SHOULD RULE?}

5 Rule by a Single Person

Single-person rule in the ancient world: Plato, Aristotle and Cicero

Medieval ideas of monarchy - Early theories of kingship:

Thomas Aquinas and Christine de Pizan

Monarchy in early modern political theory: Bodin, Hobbes, Filmer and Bossuet

Monarchy in eighteenth- and nineteenth-century political thought: Absolutists, Romantics, Maistre and Maurras

Presidents and dictators in modern political theory:

Weber and Hitler

Conclusion

6 The Rule of the Few

The rule of the few in ancient political theory:

Plato and Aristotle

Medieval and early modern conceptions of aristocracy: Aquinas, Machiavelli and Harrington 
Hereditary aristocracy in modern political theory: Burke,

Coleridge, Chateaubriand and Constant

Non-hereditary elites in modern political theory: J. S. Mill, Nietzsche, Mosca, Pareto, Blanqui and Lenin

Conclusion

7 The Rule of the Many

'The many' in ancient political theory: Protagoras, Democritus and Aristotle

'The many' in early modern political theory: classical republicans, radical Protestants and Levellers

Popular government in the age of the American and French Revolutions: Madison, Sièyes, Condorcet, Wollstonecraft, Thompson and Wheeler, Paine

Democracy in nineteenth-century political theory: James Mill, Constant, Tocqueville, J. S. Mill, Taylor, Green and Hobhouse

Socialism and democracy: Babeuf, Owen, Marx, Webb and Bernstein

Non-liberal theories of democracy in the twentieth century: 'people's' and 'Third World' democracy

Conclusion

\section{PART III THE EXERCISE OF POLITICAL AUTHORITY}

8 The Sanctions of 'Nature'

The 'natural' in ancient political theory: Plato, Aristotle and Cicero

Medieval conceptions of natural law: canon and civil law, and Aquinas

Natural rights and unlimited government in early modern political theory: Suàrez, Grotius, Hobbes and Pufendorf

Natural law, natural rights and limited government: Locke

The radical application of natural rights in eighteenth-century political theory: Rousseau, Condorcet, Paine, Wollstonecraft and Thelwall

Conclusion

9 Mixed Government, Balanced Constitutions and the Separation of Powers

Mixed government in ancient political theory: Plato, Aristotle, Polybius and Cicero 
Mixed constitutions in early modern political theory: Marsilius, Guicciardini, Machiavelli and Harrington

Separation of powers in eighteenth-century and earlynineteenth-century political theory: Montesquieu, Madison, Sièyes and Constant

Conclusion

10 Absolute Government

Monarchical supremacy and the beginnings of absolutism:

Seyssel

Legislative supremacy and absolute government: Bodin 252

Absolute sovereignty: Hobbes' Leviathan 258

Natural law, sociability and absolute government: Pufendorf 263

Absolute sovereignty and divine right monarchy:

Filmer and Bossuet

Absolute sovereignty and utilitarianism: Saint-Pierre, Bentham and Austin

Conclusion

11 The Rule of Law and Rule-Bound Orders

The rule of law in ancient political theory: Plato and Aristotle

The rule of law in medieval and early modern political theory:

'Bracton', Aquinas, Marsilius, Seyssel and Hooker

Hume's rules of justice

The rule of law in eighteenth- and early-nineteenth-century French and German theory: Montesquieu, Constant and the Rechsstaat.

Hayek's rules of justice

Conclusion

12 Resisting Unjust Rulers

Resistance in medieval political theory: Aquinas, John of Salisbury, William of Ockham and Marsilius

Resistance in early reformation political theory:

Luther and Calvin

Resistance theory in the late sixteenth century:

Beza, Hotman and Mornay

Popular sovereignty and resistance: Locke 
13 Revolutionary Political Thought

Ancient, medieval and early-modern theories of revolution:

Plato, Aristotle, radical Protestants and levellers

Natural rights and revolutionary political theory in lateeighteenth-century America and France: Otis, Sièyes and Babeuf

Marxist theories of revolution: Marx and Engels, Kautsky, Lenin, Stalin, Trotsky, Gramsci and Mao Tse-tung

Revolutionary anarchism and the critique of Marxism:

Bakunin and Kropotkin

Decolonisation and revolutionary political theory: Fanon

Conclusion

14 Theories of Civil Disobedience and Non-Violent

Resistance to Political Authority

355

Moral integrity and civil disobedience: Thoreau

356

Non-violent resistance and anticolonialism: Gandhi

Civil disobedience and just democracy: King

Conclusion

15 Conclusion: Some Contemporary Themes

Virtue and politics

Moral and political utilitarianism

Liberty, individualism and communitarianism

375

Liberal feminism

378

Natural rights, human rights and legal rights

381

Revolutionary fundamentalism

Further Reading

Bibliography

Index of Personal Names

Index of Subjects 


\section{Preface}

This book is designed to provide an introduction to the history of political thought that will be useful for students studying this subject in both history and politics programmes. It considers the full range of Western political thinking from the ancient world until the middle decades of the twentieth century and concludes with some brief indications of important developments in contemporary political theory. Although the book focuses on Western thought, it also contains a few side-glances at non-Western treatments of similar or related issues.

Unlike many introductory surveys that present a series of chronological chapters discussing the ideas of a more or less exhaustive list of important thinkers, this book focuses on themes and explores the ways in which the issues raised by them have been addressed by a range of historically significant political thinkers. This approach has been chosen with a view to identify varying responses to common or at least related concerns that have been of lasting significance to Western political thinkers. Each chapter discusses a number of thinkers who have had interesting points to make about the issues under consideration. An attempt has been made to identify the relationship between various thinkers and to trace patterns of development across extensive periods of time. Some thinkers are discussed in a number of chapters while others make a more fleeting appearance.

Three charts reflecting the conventional distinction between the ancient and medieval (c. 400 BC-1500 AD), early modern (1500-1800) and modern (1800-) periods (see pp. 7, 8, 11-12) provide a chronology that relates thinkers to one another and to major historical events. Boxes located within the text present biographical information on a wide range of important thinkers discussed in the book: the location of these is indicated by bold entries in the personal name index. 


\section{xiv Preface}

While working on this book I enjoyed a period of research leave in Cambridge. I am most grateful to the Leave Committee of Victoria University for granting me leave, and to the Warden and Fellows of Robinson College who, by electing me into a Bye Fellowship, provided a congenial environment during my stay in Cambridge. Staff of the Robinson College Library, the Cambridge University Library and the Victoria University Library have dealt courteously and efficiently with many enquiries. Miles Fairburn of the History Department at Victoria and Patrick Maloney of the Politics Department at that University have read various chapters of this books. My wife Diana Morrow has read the whole work in a number of forms and has helped me correct the proofs. Members of the Politics Department at the University of Keele responded to a seminar outlining the project, and I have also benefited greatly from the insightful and patient comments of my publisher's three anonymous readers. Adrienne Nolan has cheerfully provided valuable secretarial assistance. In thanking these people for their efforts on my behalf, and in acknowledging Steven Kennedy's efficient and encouraging editorial oversight, I do not, of course, absolve myself of responsibility for any of the shortcomings of this work. 


\section{List of 'Thinker' Boxes}

Aquinas, St Thomas 29

Aristotle 24

Augustine, St 26

Bakunin, Michael 97

Bentham, Jeremy 110

Bernstein, Eduard 192

Beza, Theodore 314

Bodin, Jean 31

Bossuet, Jaques-Benigne 268

Burke, Edmund 155

Calvin, Jean 66

Carlyle, Thomas 38

Cicero, Marcus Tullius 206

Constant, Benjamin 246

Democritus 22

Fanon, Frantz 349

Filmer, Sir Robert 136

Gandhi, Mahatma 361

Godwin, William 95

Goldman, Emma 47

Gramsci, Antonio 341

Green, T. H. 45

Grotius, Hugo 32

Harrington, James 154

Hayek, F.A. 290

Hegel, G.W.F. 87

Hitler, Adolf 144

Hobbes, Thomas 34
Hobhouse, L. T. 188

Hooker, Richard 282

Hotman, Francois 313

Hume, David 109

John of Salisbury 304

Kant, Immanuel 67

Kautsky, Karl 334

King, Martin Luther 367

Kropotkin, Peter 98

Lenin, V. I. 165

Locke, John 78

Luther, Martin 308

Machiavelli, Niccoló 64

Madison, James 177

Maistre, Joseph de 141

Mao Tse-tung 343

Marsilius of Padua 281

Marx, Karl 92

Maurras, Charles 40

Mill, James 183

Mill, John Stuart 83

Montesquieu,

Charles-Louis 243

Mornay, Phillipe 315

Mussolini, Benito 44

Nietzsche, Friedrich 161

Paine, Thomas 81

Paley, William 108 
xvi List of 'Thinker' Boxes

Pizan, Christine de 134

Sièyes, Abbè 328

Plato 23

Polybius 233

Stalin, Joseph 339

Protagoras 21

Stirner, Max 101

Proudhon, Pierre-Joseph 96

Taylor, Harriet 187

Pufendorf, Samuel 264

Thoreau, Henry 357

Rousseau, Jean-Jacques 43

Tocqueville, Alexis de 184

Seyssel, Claude de 251

Weber, Max 145

Sidgwick, Henry 119

William of Ockham 305

Wollstonecraft, Mary 179 